
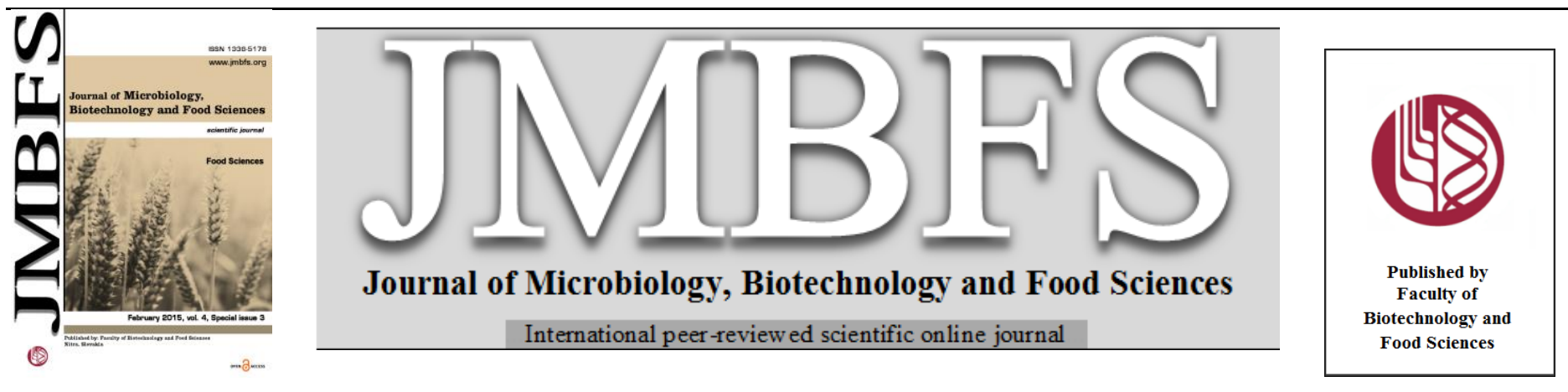

\title{
ANALYSIS OF FREE AMINO ACIDS AND BIOGENIC AMINES IN THE BULL MUSCULUS THORACIS
}

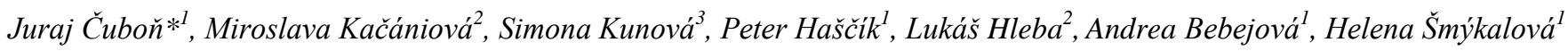

Address(es): Juraj Čubon̆, prof. Ing. PhD.

${ }^{1}$ Slovak University of Agriculture in Nitra, Faculty of Biotechnology and Food Sciences, Department of Animal Products Evaluation and Processing, Tr. A. Hlinku 2, 94976 Nitra, Slovak Republic, phone number: +421 376414428.

${ }^{2}$ Slovak University of Agriculture in Nitra, Faculty of Biotechnology and Food Sciences, Department of Microbiology, Tr. A. Hlinku 2, 94976 Nitra, Slovak Republic. ${ }^{3}$ Slovak University of Agriculture in Nitra, Faculty of Biotechnology and Food Sciences, Department of Food Hygiene and Safety, Tr. A. Hlinku 2, 94976 Nitra, Slovak Republic.

*Corresponding author:juraj.cubon@uniag.sk

doi: 10.15414/jmbfs.2015.4.special3.27-30

\section{ARTICLE INFO}

Received 20.11.2014

Revised 27. 11. 2014

Accepted 28. 11. 2014

Published 2. 2. 2015

\section{Regular article}

OPEN OACCESS $_{\text {Act }}$

\section{ABSTRACT}

Chemical composition, changes of $\mathrm{pH}$, free amino acids and biogenic amines during aging of beef Musculus thoracis during maturation were analysed. The parameters were analysed 24 hours, 48 hours, 1 week, 2 weeks and 3 weeks after slaughtering. The value of $\mathrm{pH}$ was 24 hours after slaughtering 5.6 and 48 hours similar 5.57, following the first week increased (pH 5.89) and decreased after the second week and in the third week reached $6.20 \mathrm{pH}$. During the 3 weeks ripening of meat, we found statistically significant $(\mathrm{P} \leq 0.01)$ differences only in spermidine content. Spermine content was significantly increased $(\mathrm{P} \leq 0.05)$ from $20.05 \mathrm{mg} \cdot \mathrm{kg}^{-1}$ to $48.27 \mathrm{mg} \cdot \mathrm{kg}^{-1}$. Free amino acids histamine not significant increased from 0.04 to $0.86 \mathrm{mg} \cdot \mathrm{kg}^{-1}$, also content of free amino acids ornithine increased from 0.02 to $0.37 \mathrm{mg} \cdot \mathrm{kg}^{-1}$ at the end of ripening. The putrescine content was 24 hours after slaughter $1.11 \mathrm{mg} \cdot \mathrm{kg}^{-1}$ and at $21^{\text {th }}$ day of the experiment was non significantly higher of $9.28 \mathrm{mg} \cdot \mathrm{kg}^{-1}$. Spermidine content significantly $(\mathrm{P} \leq 0.01)$ increased from 2.04 to 9.91 mg.kg ${ }^{-1}$ and spermine significantly increased $\left(\mathrm{P} \leq 0.05\right.$ ) from 20.05 to $48.27 \mathrm{mg} \cdot \mathrm{kg}^{-1}$ on the 21 th day of the experiment.

Keywords: Beef, chemical quality, $\mathrm{pH}$ value, free amino acids, biogenic amines

\section{INTRODUCTION}

In the live animal cells available oxygen through the bloodstream and can run catabolic (degradation) processes. The blood transported to the cells also energyrich compounds (e.g. glucose), and the cells $\mathrm{CO}_{2}$ transport and other degradation products to the liver or to the excretory organs such as the lungs and kidneys (Honikel, 2004).

Value of $\mathrm{pH}$ meat pre-rigor mortis phase is neutral. Unlike tissues in vivo prevail in muscle post mortem anaerobic glycolysis as sufficient stocks of muscle glycogen and glycolytic enzymes if they are actively. The partial reactions of anaerobic glycolysis can be described as follows, contains a lot of glucose, glycogen units and their removal are released from the broken bonds a heat (Garrett and Grisham, 2010; Harvey and Ferrier, 2010). At the stage of rigor mortis arising lactic acid accumulates in muscle tissue, resulting in decrease of $\mathrm{pH}$ of the muscle of the original value of about $\mathrm{pH} 6.8$ to $\mathrm{pH}<5.8$. The more acidic environment glycolytic enzymes are inhibited and a small proportion of glycogen in the muscle therefore remains unchanged. Calcium ions after the death of the animal are reacting with actin and myosin hydrolysis of ATP to ADP and inorganic phosphate (Velíšek and Hajšlová, 2009).

From the hygienic point of view biogenic amines serve as indicators of the degree of food spoilage. From a toxicological point of view may be biogenic amines precursors of carcinogenic $\mathrm{N}$-nitroso compounds (Sládková et al., 2008). In the human body endogenously synthesized biogenic amines in cellular metabolism have multiple functions. They are a source of nitrogen and precursors for the synthesis of hormones, alkaloids, nucleic acids and proteins. Can also affect processes in the body such as the regulation of body temperature, nutrient intake and blood pressure regulation (Stadnik and Dolatowski, 2010).

Tyramine and histamine also act as mediators hormone in humans and animals. Psychoactive amines such as dopamine and serotonin neurotransmitters in the central nervous system. Traditionally cadaverine, putrescine, spermine and spermidine have been classified in the group of biogenic amines. However, because of their specific biological roles in eukaryotic cells, is now out as a separate group- polyamines. They are formed by de novo synthesis and play an important role in many human and animal physiological functions (Stadnik and Dolatowski, 2012).

The occurrence of biogenic amine is mainly a consequence of the activity of bacterial decarboxylases, enzymes. These enzymes act on the free aminoacids or on the aminoacids resulted from protein hydrolysis. Polyamine spermine and spermidine are amines existing in the body and are naturally produced by it. The biogenic amines: cadaverine, putrescin, tyramine, histamine, tryptamine, $\beta$ phenylethylamine are formed during storage of meat due to microorganism activity. The decrease in time of spermidine and spermine is due to their use as nitrogen sources by microorganisms (Balamatsia et al., 2007).

Biogenic amines are identified by the group of low molecular weight basic compounds with aliphatic (putrescine, cadaverine, spermine, spermidine), aromatic (tyramine, phenylethylamine) or heterocyclic structure (histamine, tryptamine). Biogenic amines are degradation products in the bacterial decomposition of substances contained in food (Lunestand et al., 2011).

Polyamines putrescine, spermidine and spermine form a group of amines classified due to their formation by de novo biosynthesis (putrescine $\rightarrow$ spermidine $\rightarrow$ spermine) as natural or physiological polyamines, while biogenic amines (mainly histamine, tyramine, phenylethylamine, putrescine and cadaverine) are formed by non-specific bacterial decarboxylation of amino acids. However, putrescine is classified in both groups.

The polyamines are flexible polycations with two, to four positive charges distributed along their hydrocarbon chain. It enables formation of bridges between distant negatively charged structures and polyamines can therefore fulfil a wide range of unique and indispensable roles in human metabolism. They are involved in nearly each step of nucleic acid and protein synthesis, and are thus essential for cell proliferation and growth. The requirement for polyamines therefore increases in rapidly growing tissues. The importance of polyamines in tumour growth is widely recognised. One of the directions in cancer therapy research is to limit intake of polyamines. Nevertheless, every organ of the body requires polyamines for its growth, renewal and metabolism, depending on the physiological and pathological state of an individual (Moinard et al., 2005).

The product of decarboxylation of histidine is histamine. From lysine after cleavage carboxyl group with an amine lysine decarboxylase occurs cadaverine. Putrescine can be formed by several biochemical pathways. Decarboxylation of 
arginine for action arises arginin decarboxylase agmatine and putrescine further. Putrescine can also be formed directly by decarboxylation of ornithine participation of ornithine decarboxylase. From putrescine may methylation Sadenosylmethionine formed spermidine and spermine further. Decarboxylation product of the amino acid tryptophan for action tryptofan decarboxylase is Tryptamine, activity tyrosine decarboxylase to form tyramine. Decarboxylation occurs fenylalanin dekarboxylase phenylalanine 2-phenylethylamine (Velíšek and Hajšlová, 2009).

The aim of the paper was analysed free amino acids and biogenic amines during ripening of 21 days in the bulls Musculus thoracis.

\section{MATERIAL AND METHODS}

The bulls crosses of the Slovak Pied and Charolais breeds $(n=10)$ were fattened to 15 months of age. Bulls were slaughtered at the commercial slaughterhouse, 24 hours after slaughtering were deboned and Musculus thoracis was used for analyses. The $\mathrm{pH}$ value, free aminoacids and biogenic amines were analysed 24 hours, 48 hours, 1 week, 2 weeks and 3 weeks after slaughtering. The samles of Musculus thoracis matured at $4{ }^{\circ} \mathrm{C}$.

The $\mathrm{pH}$ value was analysed by Gryf $200 \mathrm{~L}$ pH meater (Havlíčkův Brod, Czech Republic) at $20^{\circ} \mathrm{C}$ ). Free aminoacids and biogenic amines were determined by using ion-exchange chromatography (AAA400 Amino Acid Analyzer; Ingos, Prague, Czech Republic) as was described by Buňková et al. (2009). Each incubated broth was analysed at least twice. Standards were supplied by SigmaAldrich. Free aminoacids citrulline, cysteine, aminoadipic acid were not detected in meat.

The results were statistically evaluated by statistical programe SAS. The significant differences were found out only between meat parameters of 24 hours and 3 weeks after slaughtering.

\section{RESULTS AND DISCUSION}

Table. 1 shows the change in $\mathrm{pH}$ of the samples during maturing to 21 days after slaughtering. The $\mathrm{pH}$ value of the samples was measured after 24 and 48 hours and after 1, 2 and 3 weeks. After 24 hours, was the average value of $\mathrm{pH} 5.60$ in Musculus thoracis. Simek et al. (2003) found out in bulls Musculus thoracis slightly lower values ( $\mathrm{pH} 5.43) 24$ hours after slaughter. The value of $\mathrm{pH}$ was 24 hours after slaughtering 5.6 and 48 hours similar 5.57, following the first week increased ( $\mathrm{pH} 5.89)$ and decreased after the second week and in the third week reached $6.20 \mathrm{pH}$. The analysis shows a bimodal curve of the $\mathrm{pH}$.

Table 1 Value of $\mathrm{pH}$ of bulls Musculus thoracis in the meat aging $(\mathrm{n}=10)$

\begin{tabular}{|c|c|c|c|c|c|}
\hline & $\mathrm{pH}_{24}$ & $\mathrm{pH}_{48}$ & $\mathbf{p H}_{1 \mathrm{w}}$ & $\mathbf{p H}_{2 \mathrm{~W}}$ & $\mathrm{pH}_{3 \mathrm{~W}}$ \\
\hline $\mathrm{CV} \%$ & 6,10 & 6,08 & 2,26 & 1,80 & 7,14 \\
\hline
\end{tabular}

slaughtering, $\mathbf{p H}_{3 \mathrm{w}}-\mathrm{pH} 3$ weeks after slaughtering.

Table. 2 shows the basic chemical parameters of bulls Musculus thoracis, the average protein content was $21.74 \%$ w/w, $76.03 \%$ w/w moisture and $0.8 \%$ w/w ash. Low intramuscular fat content $1.43 \% \mathrm{w} / \mathrm{w}$ points to the low degree of marbling. Similarly with our results found out Weglarz (2010) the moisture

Table 2 Basic chemical parameters of bulls Musculus thoracis $(\mathrm{n}=10)$

\begin{tabular}{|c|c|c|c|c|c|}
\hline & $\begin{array}{l}\text { Proteins } \\
(\% \mathrm{w} / \mathrm{w})\end{array}$ & $\begin{array}{l}\text { Intramuscular } \\
(\% \mathrm{w} / \mathrm{w})\end{array}$ & fat & $\begin{array}{l}\text { Moisture } \\
(\% \text { w/w })\end{array}$ & $\begin{array}{l}\text { Asch } \\
(\% \text { w/w })\end{array}$ \\
\hline Mean & 21,74 & 1,43 & & 76,03 & 0,80 \\
\hline S.D. & 0,76 & 0,31 & & 0,51 & 0,08 \\
\hline CV \% & 3,53 & 22,44 & & 0,66 & 10,06 \\
\hline
\end{tabular}

Table. 3 shows that not all free amino acid content increases proportionally with the time of maturation, but there was an increase of their contents and the subsequent decline and eventual rebound in content. In the Musculus thoracis we reported this phenomenon in glutamine, alanine, $\gamma$-aminobutyric acid, ethanolamine, and $\alpha$-aminobutyric acid. This phenomenon could be caused by the formation of biogenic amines by the action of free amino acids of native and microbial enzymes.

In the Musculus thoracis content of almost all observed amino acid was changed specific biogenic amines during ripening of meat have increased concentration of histamine biogenic amines and polyamines putrescine and spermidine and phenylethylamine, tyramine, cadaverine and agamatine were not detected in stage of maturation.

The first day after slaughtering was histamine content (mg. $\left.\mathrm{kg}^{-1} 1\right) 0.85$, spermine 20.05 , spermidine 2.04 , putrescine $1.11^{1}$. On the $14^{\text {th }}$ day of ripening histamine content increased to 2.44 , spermine 34.60 , spermidine 5.92 and putrescine 7.89 $\mathrm{mg} \cdot \mathrm{kg}^{-1}$. During the ripening of meat, we found statistically significant $(\mathrm{P} \leq 0.01)$ differences only in spermidine where content increased from $2.04 \mathrm{mg} . \mathrm{kg}^{-1}$ to 9.91 $\mathrm{mg} \cdot \mathrm{kg}^{-1}$. So was significantly increased $(\mathrm{P} \leq 0.05)$ spermine content from 20.05 mg.kg ${ }^{-1}$ to $48.27 \mathrm{mg} . \mathrm{kg}^{-1}$. These values are consistent with the range of the levels of biogenic amines and polyamines in beef, which showed Velíšek and Hajšlová (2009) (histamine 0-217 mg. $\mathrm{kg}^{-1}$, spermine 5-40 mg.kg ${ }^{-1}$, spermidine trace to 5 $\mathrm{mg} \cdot \mathrm{kg}^{-1}$ and putrescine trace to $26 \mathrm{mg} \cdot \mathrm{kg}^{-1}$ ).

Spermine content in the samples was higher than the content of spermidine, which was consistent with the argument Krausová et al. (2008). In our samples were detected phenylethylamine, tyramine, cadaverine and agmatine, which was in line with and Velíšek Hajšlová (2009) who reported content in beef cadaverine $0-27 \mathrm{mg} \cdot \mathrm{kg}^{-1}$, agmatine $2-112 \mathrm{mg} \cdot \mathrm{kg}^{-1}$. The amount of tyramine trace spermine proportionally with increasing aging time (Tab. 4). Biogenic amines content $74.53 \% \mathrm{w} / \mathrm{w}$ and total protein $22.26 \%$ w/w. Bobček et al. (2010) w/w. compared with our results found out a higher content of intramuscular fat $2.30 \%$

mg. $\mathrm{kg}^{-1}$ and phenylethylamine was not detected. On the other hand Capillas and Colmenero (2005) reported lower content of biogenic amines in raw beef, where the histamine content was from 0 to $1.1 \mathrm{mg} \cdot \mathrm{kg}^{-1}$, putrescine 0 to $1.75 \mathrm{mg} . \mathrm{kg}^{-1}$, spermidine 1.9 to $4.2 \mathrm{mg} \cdot \mathrm{kg}^{-1}$, spermine 28.7 to $44.6 \mathrm{mg} \cdot \mathrm{kg}^{-1}$.

\section{CONCLUSION}

The work analyzed the quality of beef during maturation. Analyzed were chemical composition, changes of $\mathrm{pH}$, free amino acids and biogenic amines during aging of Musculus thoracis. The parameters were analysed 24 hours, 48 hours, 1 week, 2 weeks and 3 weeks after slaughtering. The samples of Musculus thoracis matured at $4{ }^{\circ} \mathrm{C}$. The value of $\mathrm{pH}$ was 24 hours after slaughtering 5.6 and 48 hours similar 5.57, following the first week increased $\mathrm{pH} 5.89$ and decreased after the second week and in the third week reached $6.20 \mathrm{pH}$.

During the ripening of meat, we found statistically significant $(\mathrm{P} \leq 0.01)$ differences only in spermidine where content increased from 2.04 to $9.91 \mathrm{mg} . \mathrm{kg}$ 1. So was significantly increased $(\mathrm{P} \leq 0.05)$ spermine content from $20.05 \mathrm{mg} . \mathrm{kg}^{-1}$ to $48.27 \mathrm{mg} . \mathrm{kg}^{-1}$.

Based on our results we can conclude that the content of free amino acids histamine not significant increased from 0.04 to $0.86 \mathrm{mg} . \mathrm{kg}^{-1}$, also content of free amino acids ornithine increased from 0.02 to $0.37 \mathrm{mg} \cdot \mathrm{kg}^{-1}$ at the end of ripening The product of ornithine is a biogenic amine putrescine, where we found 24 hours after slaughter content and $1.11 \mathrm{mg} \cdot \mathrm{kg}^{-1}$ at $21^{\text {th }}$ day of the experiment was non significantly higher of $9.28 \mathrm{mg} \cdot \mathrm{kg}^{-1}$. Putrescine is metabolized to spermine and spermidine. Spermidine content significantly $(\mathrm{P} \leq 0.01)$ increased from 2.04 to $9.91 \mathrm{mg} \cdot \mathrm{kg}^{-1}$ and spermine significantly increased $(\mathrm{P} \leq 0.05)$ from 20.05 to $48.27 \mathrm{mg} \cdot \mathrm{kg}^{-1}$ on the $21^{\text {th }}$ day of the experiment. 
Table 3 Content of free amino acids during ripening of bulls Musculus thoracis ( $\left.\mathrm{mg} \cdot \mathrm{kg}^{-1}\right)$

\begin{tabular}{|c|c|c|c|c|c|c|c|c|c|c|c|c|c|}
\hline & $1^{\text {st day }}$ & & & $7^{\text {th }}$ day & & & $14^{\text {th }} d \mathrm{~d}$ & & & ${ }^{21 \text { th }} \mathrm{da}$ & & & t-test \\
\hline & mean & S.D. & $\mathrm{CV} \%$ & mean & S.D. & $\mathrm{CV} \%$ & mean & S.D. & $\mathrm{CV} \%$ & mean & S.D. & $\mathrm{CV} \%$ & \\
\hline arginine & 0.02 & 0.01 & 2.79 & 0.04 & 0.01 & 16.40 & 0.09 & 0.07 & 72.90 & 0.19 & 0.16 & 87.10 & \\
\hline threonine & 0.03 & 0.01 & 45.87 & 0.04 & 0.02 & 44.02 & 0.09 & 0.07 & 79.20 & 0.12 & 0.09 & 71.60 & $S$ \\
\hline serine & 0.02 & 0.01 & 7.23 & 0.04 & 0.01 & 24.67 & 0.04 & 0.02 & 34.10 & 0.06 & 0.07 & 110.10 & $S$ \\
\hline aspartic acid & 0.32 & 0.06 & 19.63 & 0.53 & 0.13 & 25.37 & 0.77 & 0.02 & 2.71 & 0.93 & 0.07 & 7.25 & + \\
\hline asparagine & 0.02 & 0.01 & 30.69 & 0.04 & 0.01 & 22.96 & 0.20 & 0.03 & 13.92 & 0.25 & 0.07 & 26.02 & + \\
\hline glutamic acid & 0.46 & 0.07 & 15.09 & 0.81 & 0.34 & 44.68 & 0.46 & 0.66 & 135.90 & 0.59 & 0.80 & 114.24 & $\sqrt{S}$ \\
\hline glutamine & 0.02 & 0.02 & 88.94 & 0.03 & 0.00 & 5.30 & 0.04 & 0.00 & 4.86 & 0.09 & 0.03 & 31.06 & \\
\hline proline & 0.02 & 0.01 & 6.56 & 0.04 & 0.01 & 25.13 & 0.09 & 0.08 & 83.83 & 0.16 & 0.16 & 98.31 & \\
\hline glycine & 0.19 & 0.02 & 11.49 & 0.32 & 0.02 & 7.56 & 0.56 & 0.26 & 47.66 & 0.36 & 0.12 & 35.37 & -+ \\
\hline alanine & 0.03 & 0.01 & 16.61 & 0.04 & 0.00 & 7.01 & 0.16 & 0.13 & 83.19 & 0.31 & 0.30 & 88.25 & \\
\hline valine & 0.01 & 0.01 & 4.31 & 0.03 & 0.00 & 7.40 & 0.11 & 0.09 & 84.81 & 0.21 & 0.18 & 82.03 & + \\
\hline methionine & 0.02 & 0.01 & 13.43 & 0.03 & 0.00 & 3.35 & 0.12 & 0.11 & 86.80 & 0.20 & 0.15 & 75.94 & \\
\hline isoleucine & 0.03 & 0.01 & 14.89 & 0.06 & 0.00 & 0.95 & 0.19 & 0.16 & 81.93 & 0.34 & 0.30 & 83.92 & \\
\hline leucine & 0.01 & 0.01 & 26.31 & 0.03 & 0.01 & 17.54 & 0.12 & 0.12 & $9 ., 4$ & 0.16 & 0.14 & 85.03 & + \\
\hline tyrosine & 0.02 & 0.00 & 1.18 & 0.03 & 0.01 & 10.13 & 0.10 & 0.07 & 69.52 & 0.21 & 0.21 & 96.32 & \\
\hline phenylalanine & 0.01 & 0,00 & 25.53 & 0.02 & 0.01 & 44.33 & 0.05 & 0.05 & 115.06 & 0.14 & 0.13 & 99.62 & \\
\hline$\beta$-alanine & 0.02 & 0.01 & 71.05 & 0.02 & 0.00 & 13.75 & 0.03 & 0.03 & 90.44 & 0.04 & 0.00 & 0.12 & \\
\hline$\beta$-aminobutyric acid & 0.00 & 0.01 & 40.35 & 0.01 & 0.00 & 3.46 & 0.08 & 0.09 & 99.64 & 0.04 & 0.03 & 86.80 & \\
\hline$\gamma$-aminobutyric acid & 0.03 & 0.02 & 78.30 & 0.06 & 0.01 & 18.88 & 0.10 & 0.05 & 51.11 & 0.08 & 0.01 & 20.40 & \\
\hline ethanolamine & 0.02 & 0.01 & 16.95 & 0.05 & 0.01 & 17.38 & 0.08 & 0.06 & 74.53 & 0.14 & 0.10 & 86.64 & \\
\hline ornithine & 0.02 & 0.01 & 22.27 & 0.07 & 0.02 & 22.90 & 0.10 & 0.07 & 68.20 & 0.37 & 0.32 & 88.22 & \\
\hline lysine & 0.01 & 0.00 & 30.55 & 0.05 & 0.01 & 16.40 & 0.08 & 0.05 & 67.90 & 0.11 & 0.09 & 72.35 & \\
\hline histidine & 0.40 & 0.11 & 26.70 & 0.62 & 0.27 & 40.23 & 0.72 & 0.18 & 25.04 & 0.86 & 0.33 & 40.21 & VS \\
\hline 1-methylhistidine & 0.02 & 0.02 & 67.70 & 0.04 & 0.01 & 28.83 & 0.04 & 0.04 & 107.23 & 0.06 & 0.03 & 42.42 & \\
\hline$\alpha$-aminobutyric acid & 0.01 & 0.01 & 52.80 & 0.01 & 0.00 & 2.35 & 0.03 & 0.03 & 85.36 & 0.02 & 0.01 & 49.29 & $\sqrt{S}$ \\
\hline
\end{tabular}

Legend: $\mathrm{NS}=(\mathrm{P}>0.05),+(\mathrm{P} \leq 0.05),++(\mathrm{P} \leq 0.01)$

Table 4 Content of biogenic amines during ripening of bulls Musculus thoracis (mg.kg-1)

\begin{tabular}{|c|c|c|c|c|c|c|c|c|c|c|c|c|c|}
\hline & \multirow{2}{*}{$\begin{array}{l}1^{\text {st }} \text { day } \\
\text { mean }\end{array}$} & \multirow[b]{2}{*}{ S.D. } & \multirow[b]{2}{*}{$\mathrm{CV} \%$} & \multicolumn{2}{|c|}{$7^{\text {th }}$ day } & \multirow[b]{2}{*}{ CV \% } & \multicolumn{2}{|c|}{$14^{\text {th }}$ day } & \multirow[b]{2}{*}{ CV \% } & \multicolumn{2}{|c|}{${ }^{21 \text { th }}$ day } & \multirow[b]{2}{*}{$\mathrm{CV} \%$} & \multirow[t]{2}{*}{ t-test } \\
\hline & & & & mean & S.D. & & mean & S.D. & & mean & S.D. & & \\
\hline \multirow{2}{*}{$\begin{array}{l}\text { histamine } \\
\text { phenylethylami } \\
\text { ne }\end{array}$} & 0.85 & 0.45 & 51.83 & 1.33 & 0.66 & 49.31 & 2.44 & 1.72 & 69.91 & 4.01 & 2.43 & 60.86 & \multirow{2}{*}{ NS } \\
\hline & ND & & & ND & & & ND & & & ND & & & \\
\hline tyramine & ND & & & ND & & & ND & & & ND & & & \multirow[b]{2}{*}{ NS } \\
\hline putrescine & 1.11 & 0.75 & 67.74 & 2.56 & 2.14 & 83.79 & 6.94 & 7.89 & 113.98 & 9.28 & 9.89 & 106.65 & \\
\hline cadaverine & ND & & & $\mathrm{ND}$ & & & ND & & & ND & & & \\
\hline agmatine & ND & & & ND & & & ND & & & ND & & & \\
\hline spermidine & 2.04 & 0.17 & 8.38 & 4.43 & 0,83 & 18.72 & 5.92 & 0,85 & 14.32 & 9.91 & 0.46 & 4.61 & ++ \\
\hline spermine & 20.05 & 10.29 & 51.31 & 27.81 & 9.63 & 34.62 & 34.60 & 14.81 & 42.77 & 48.27 & 1.18 & 2.42 & + \\
\hline
\end{tabular}

Acknowledgments: This work was supported by the VEGA no. 1/0611/14.

\section{REFERENCES}

BALAMATSIA, C. C. PALEOLOGOS, E. K. KONTOMINAS, M. G. SAVVAIDIS, I.N. 2007. Possible role of volatile amines as quality indicating metabolites in modified atmosphere packaged chicken fillets: Correlation with microbiological and sensorial attributes. Food Chemistry, 104, 4, 1622-1628. http://dx.doi.org/10.1016/j.foodchem.2007.03.013
BOBČEK, B. - MRÁZOVÁ, J. - BUČKO, O. - VAVRIŠÍNOVÁ, K. GAJDOŠOVÁ, L. 2010. Bravčové a hovädzie mäso obohatené organickým selénom a jeho vplyv na nutričné a technologické vlastnosti vo vzt'ahu na selénový status l'udí. In Acta fytotechnica et zootechnica, 16-19.

BUŇKOVÁ, L. BUŇKA, F. HLOBILOVÁ, M. VAŇÁTKOVÁ, Z NOVÁKOVÁ, D. DRÁB, V. 2009. Tyramine production of technological important strains of Lactobacillus, Lactococcus and Streptococcus. European Food Research and Technology, 229, 533-538. http://dx.doi.org/10.1007/s00217009-1075-3 
CAPILLAS, R. C. COLMENERO, J. F. 2005. Biogenic amines in meat and meat products. Critical Reviews in Food Science and Nutrition, 44, 489-599. http://dx.doi.org/10.1080/10408690490489341

ELIASSEN, K.A. REISTAD, R. RISØEN, U. RØNNING H.F. 2002. Dietary polyamines. Food Chemistry, 78, 273-280. http://dx.doi.org/10.1016/s03088146(01)00405-8

GARRETT, R. H. - GRISHAM, CH. M. 2010. Biochemistry. 4. ed. Boston : Brooks/Cole, 2010. 1141 p. ISBN 978-0-495-10935-8.

HARVEY, R. A. - FERRIER, D. R. 2010. Biochemistry. 5. ed. Philadelphia : Wolters Kluwer Health, 2010. 520 p. ISBN 978-1608314126.

HONIKEL, K. O. 2004. Conversion of Muscle to Meat - Glycolysis. In Jensen, W. K. - Devine, C. - Dikeman, M. (eds.). 2004. Encyclopedia of meat sciences. Oxford : Academic Press, 2004. p. 314-318. ISBN 0-12-464970-X.

KRAUSOVÁ, P. KALAČ, P. KŘíŢEK, M. PELIKÁNOVÁ, T. 2008. Changes in the content of biologically active polyamines during pork loin storage and culinary treatments. European Food Research and Technology, 226, 2008, 5,1007-1012. http://dx.doi.org/10.1007/s00217-007-0625-9

MOINARD, C. CYNOBER, L. DE BANDT, J.P. 2005. Polyamines: metabolism and implications in human disease. Clinical Nutrition, 24. 184-197. http://dx.doi.org/10.1016/j.clnu.2004.11.001

LUNESTAND, B. T. LEVSEN, A. ROSNES, J. T. 2011. Tracing pathogens in fish production chains. In Brul, S. - Fratamico, M. P. - McMeekin, A.T. (eds.)

2011. Tracing Pathogens in the Food Chain. Woodhead Publishing, 2011. 433464. ISBN 978-1-61344-378-1.

SLÁDKOVÁ, P. 2008. Vybrané faktory ovlivňující obsah biogenních aminů ve fermentovaných masných výrobcích. In MendelNET'2008 Agro : Proceedings of International Ph.D. Students Conference. Brno : Mendelova Zemědělská a Lesnická Univerzita v Brně, 2008, p. 91. ISBN 978-80-7375-239-2.

STADNIK, J. DOLATOWSKI, Z. J. 2010. Biogenic amines in meat and fermented meat products. Acta Scientarium Polonorum, Technologia Alimentaria, 9, 3, 251-263.

STADNIK, J. - DOLATOWSKI, Z. J. 2012. Biogenic amines content during extended ageing of dry-cured pork loins inoculated with probiotics. Meat Science, 91, 3, 374-377. http://dx.doi.org/10.1016/j.meatsci.2012.02.022

ŠIMEK, J. VORLOVÁ, L. MALOTA, L. STEINHAUSEROVÁ, I. STEINHAUSER, L. 2003. Post-mortal changes of $\mathrm{pH}$ value and lactic acid content in the muscles of pigs and bulls. Czech Journal of Animal Science, 48, 7 , 295-299.

WEGLARZ, A. 2010. Quality of beef from semi-intensively fattened heifers and bulls. Animal Science Papers and Reports, 28, 3, 207-218.

VELÍŠEK, J. - HAJŠLOVÁ, J. 2009. Chemie potravin 1. 3. ed. Tábor : OSSIS, 2009. 602 p. ISBN 978-80-86659-15-2. 